\title{
SELF-EVALUATION AND SELF-ASSESSMENT IN SCIENCE TEACHER TRAINING
}

\author{
Danuse Nezvalova \\ Palacky University, Olomouc, Czech Republic
}

\begin{abstract}
This paper will build on the findings of a pilot study to investigate the extent to which self- assessment and self-evaluation are implemented to assess science teacher students and to put into practice reformed assessment system. The self-assessment and self-evaluation in science teacher education is $s$ an important aspect of quality in science teacher training. Currently these approaches to assessment have called for more authentic student assessment. Teachers who include authentic assessment in their repertoires are driven by a belief that alternative assessment experiences should prepare students for life in the real world. While teacher-made tests give us information about student learning, they do not provide all the information. Alternate forms of assessment can generate that other information.
\end{abstract}

Key words: science teacher training, self-assessment, self-evaluation, quality of science teacher training.

\section{Introduction}

Teachers today are experimenting with alternatives to traditional tests. Performance assessment, portfolio collections, classroom observation, peer assessment, self-assessment and self-evaluation are joining the unit test and the final exam in the repertoire of the skillful teacher. Such teachers ensure that an over-reliance on testing does not seriously distort lectures or impede important institution improvement efforts. Accordingly, their programs are based on a range of assessment approaches. Teachers who include authentic assessment in their repertoires are driven by a belief that alternative-assessment experiences should prepare students for life in the real world. While teacher-made tests give us information about student learning, they do not provide all the information. Alternate forms of assessment can generate that other information.

\section{Background}

Self-evaluation and self-assessment are strategies for involving students in assessing and evaluating their learning and self-assessment is the formative ongoing component (Bound, 1992). We tried to introduce self-assessment and self-evaluation into a teaching methods course, Teaching science in school. This was an experience unfamiliar to many interns of the science method class that is the focus of this study. Our goal for implementing self-assessment and self-evaluation was that it would encourage each intern to focus on his/her learning rather than other behavioral aspects that sometimes become conflated with learning in assessment. During the course, interns were involved in self-assessment tasks and at course completion wrote a narrative that was to contain an argument for a self-based on evidence of learning. Engaging future high school science teachers with the task of assessing their learning involved them in authentic experiences addressing questions that had implications for their future roles as teachers.

For the last several years we have been working with prospective science teachers to develop alternate forms of authentic student assessment strategies. The research evidence accumulating in our studies, and the data produced by other researchers, make us optimistic about the impact of one form of authentic assessment - self-evaluation and self-assessment - on the learning of students.

The Nature of Self-Assessment 
With the release of the constructivist approach to science teaching, the issues of why, how, and what we, as teachers, assess in our classrooms will become a major challenge in the science teaching and learning. As educators are changing their ideas about what constitutes exemplary inquiry-based learning, and recognizing that science is an active process that encourages higher-order thinking and problem solving, there is an increased need to align assessment (Bransdorf, et al., 2000).

Assessment can be defined as a sample taken from a larger domain of content and process skills that allow one to infer student understanding of a part of the larger domain being explored. The sample may include behavior, products, knowledge, and performances. Assessment is a continuous, ongoing process that involves examining and observing student's behavior, listening to their ideas, and developing questions to promote conceptual understanding. The term authentic assessment is often referred to in any discussion of assessment and can be thought of as an examination of student performance and understanding on significant tasks that have relevancy to the student's life inside and outside of the classroom (Angelo, Cross 1993).

Davies and Wavering (1999) defined self-evaluation as a form of alternative assessment that used reflection as both a process and a product and recommended the use of journals and exit cards as a strategies for monitoring student thinking.

Self-evaluation is defined as students judging the quality of their work, based on evidence and explicit criteria, for the purpose of doing better work in the future. Self-evaluation is a potentially powerful technique because of its impact on student performance through enhanced self-efficacy and increased intrinsic motivation. Evidence about the positive effect of selfevaluation on student performance is particularly convincing for difficult tasks (Maehr \& Stallings, 1972; Arter et al., 1994, Hughes et al., 1985). Perhaps just as important, students like to evaluate their work.

\section{The Purpose of Assessment}

Assessment is changing for many reasons. The valued outcomes of science learning and teaching are placing greater emphasis on the student's ability to inquire, to reason scientifically, to apply science concepts to real-world situations, and to communicate effectively what the student knows about science. Assessment of scientific facts, concepts, and theories must be focused not only on measuring knowledge of subject matter, but on how relevant that knowledge is in building the capacity to apply scientific principles on a daily basis. The teacher's role in the changing landscape of assessment requires a change from merely a collector of data, to a facilitator of student understanding of scientific principles.

Self-assessment and self-evaluation have been found to support critical thinking (Bound 1986; McMahon, 1999), autonomy (Laurillard, 1997), the construction of deeper knowledge of the topic (Sadler, Good, 2006), life-long learning (Dochy, et al., 1999; Boud, 1986) and demystification of assessment and while building awareness (Taras, 2001). Dochy and McDowell (1997) argued self-evaluation assisted students to develop other skills in areas such as communication, self-evaluation, observation and self-criticism.

\section{Characteristics of Assessment}

The assessment is learner-centered, teacher-directed, mutually beneficial, formative, context-specific, ongoing, and rooted in good teaching practice. In the context of constructivist approach, assessments need to gauge the progress of students in achieving the three major learning outcomes of constructivist approach: conceptual understanding in science, abilities to perform scientific inquiry, and understandings about inquiry (Valanides, Hadjiachilleos, 2006).

All learners come to learning tasks with some relevant knowledge, feelings and skills. Students have already attained several thousand concepts and language labels for these con- 
cepts. Learners do not store concepts as isolated bits; instead, they form relationships or connections between concepts to form propositions. Meaningful learning occurs when the learners seek to relate new concepts and propositions to relevant existing concept and propositions in her/his cognitive structure (Novak, 2002).

Teachers have a very challenging role to play in assessment process. They must seek to understand the major superordinate and subordinate concepts of the sciences and integrate these into a complex, integrated, hierarchical structure. Assessment can foster development of the kind of knowledge frameworks that are needed for effective science teaching. So prospective science teachers must seek on their own initiative to build this kind of understanding of their field. As it is focused on learning, assessment requires the active participation of students. By cooperating in assessment, students reinforce their grasp of the science content and strengthen their own skills and self-assessment and self-evaluation.

Authentic assessment is formative rather than summative. Its purpose is to improve the quality of student learning, not to provide evidence for evaluating or grading students. Assessment has to respond to the particular needs and characteristics of the teachers, students and science content.

\section{Shifts in Conceptions of Assessment}

Four major shifts in conceptions of assessment influence how we consider supporting prospective science teachers with the adoption of approaches such as self-evaluation.

First, as part of a broader assessment reform movement, conceptions of good assessment are moving toward direct observation of complex performance rather than brief written tests that correlate with the target aptitudes (Linn et al., 1991). In these alternate assessments, students are observed working with complex tasks (for example, Baron, 1990; Shavelson et al., 1992) or dealing with real-life problems (Raizen, Kaser, 1989).

Second, shift to alternate assessment have been mixed. Mandated alternate assessment programs can produce teacher resistance due to schedule disruption, concerns about consistency, and doubts about the usefulness of the data (Wilson, 1992; Howell et al., 1993; Maudaus, Kellaghan, 1993; Worthen, 1993). Yet, when teachers have the freedom to choose, there is enthusiasm for alternate assessment (Calfee, 1993; Bateson, 1994).

Alternate conceptions of evaluation escalate demands on teachers. Alternate assessment must be transparent (Fredericksen, Collins, 1989), meaning that the criteria for appraisal, the population from which tasks are drawn, the scoring key and interpretive schemes must be visible to students, even when the teachers who devised these procedures have an imperfect grasp of them. Asking teachers to engage students in setting evaluation criteria (Bellanca, Berman, 1994; Garcia, Pearson, 1994) intensifies demands. Authentic assessment standards require precise specification of what will be measured, identification of multiple levels of attainment, and descriptions of opportunities to learn (Linn, 1994). The heightened concern with the moral dimension of evaluation (for example, Wiggins, 1993) requires that teachers support due process and allow students to be assessed at an appropriate level of difficulty, when ready.

Third, making such changes is not easy. Briscoe (1994) found that when beliefs about teaching and the constructivist learning theory implicit in alternate assessment conflicted, conventional test practices returned. Shifting to assessments based on observations and interviews to accommodate experiments with constructivist teaching can create conflicts. Some studentteachers can treat only formal tests as valid assessment procedures.

Finally, one of the most challenging shifts in conceptions of assessment is related to the changing role of the educator and the changing educational environment. The context for educators is changing rapidly and dramatically. It is more complex and volatile. As Hargreaves, Fullan (1998) state, "In times of turbulent social change, redefining one's relationship to the envi- 
ronment is crucial" (p. 4). If we value "participation, equality, inclusiveness and social justice," (Hargreaves, Fullan, 1998, p. 13), then our institutions need to be places where students share leadership and responsibility for learning. In such a shifting context our outcomes for students have sufficiently changed and traditional assessment practices are no longer adequate.

All of these factors place the demand on prospective teachers to develop assessment literacy themselves. We define assessment literacy as the: 1) capacity to examine student data and make sense of it;2) ability to make changes in teaching and schools derived from those data; and 3) commitment to engaging in external assessment discussions. Developing assessment literacy facilitates teacher confidence about the defensibility of their evaluation practices and reduces feelings of vulnerability. It means that teachers are able to provide the home with clear and detailed assessments, and are able to provide a rationale for the assessment choices they make in their classrooms. Becoming more assessment literate also means teachers becoming critical consumers of externally generated assessment data so that they can engage in the arguments about standards and accountability (Hargreaves, Fullan, 1998). Educators who can clearly and respectfully discuss assessment issues with non-educators and educators alike, will be better able to link student learning and instructional approaches for the purpose of continuous improvement.

Four conceptual shifts have just been elaborated: 1) the movement toward direct observation of complex performance rather than brief written tests; 2) the mixed responses by teachers to alternate assessment; 3 ) the difficulty in making assessment changes; and 4) the changing role of the teacher and the changing educational environment that necessitates the need for teacher assessment literacy. In our quest to more clearly understand self-evaluation, and in working with prospective teachers to help students get better at self-evaluation, it has been important for us to keep these shifts front and center.

It is important in teaching students how to be self-evaluators is to deal with their misconceptions or pre-determined views of self-evaluation (Ross et al., 1999; Dekkers, Thijs, 1998). They often described it as „marking yourself“. We need to move beyond this definition to help students see the role that criteria play in the judgment of their work.

Students might be provided with a simple definition such as: Self-evaluation is judging the quality of your work. Over time, however, or with students we would want to expand this definition to include the following two dimensions: self-evaluation is judging the quality of your work, based on evidence and explicit criteria, for the purpose of doing better work.

\section{Usefulness for students}

The trainee used the self-assessment and self-evaluation during the course. The trainee chose several teaching methods, self-assessment and self-evaluation methods to engage and motivate the students. These included: discussion, role play, case studies, student presentations, portfolio, project work, group work, computer aided learning, text based learning, misconception check, minute paper, word journal ...

The trainee evaluated the use of self-assessment and self-evaluation positively. They thought that the teacher-students enjoyed the learning in the courses. Students can better understand this approach to assessment and a function of formative characteristics of self-assessment and self-evaluation in science education. They can use techniques for assessing knowledge, skills, learner attitudes, values and self-awareness in their teaching practice in school and in their science teaching in the future. Students got competency to assess pupils learning, to use multiple assessment tools and strategies to assess pupils' knowledge, skills and values and modify instruction on the basis of formative assessment.

Prospective science students felt confident using the self-assessment and self-evaluation materials in this way. In the end of the course all (24) these students received the questionnaires 
and filled them. The questions were opened or used the scale 1 (excellent) -5 (very low) in the questionnaire. In the first opened question students were asked about their expectation and fulfilment. Majority of students answered that their expectations were fulfilled. In the next opened questions students should explain what they evaluate positively, in a negative way and what they suggest to change. Positive answers included: doing presentations, interesting contain and topics, opened discussion, used self-assessment methods and strategies, understanding of new approaches to assessment and evaluation, possibility to have influence on final evaluation of the course, possibility to participate on the design of criteria, higher motivation to learn the content of the course. Negative answers included: working in groups and cooperation between students and difficulties to evaluate their work. Students do not like to work in groups too much and most of them were not able to exchange and share their work and ideas electronically. Students mostly did not suggest any changes.

Detailed results of the scaled part of the questionnaire ( 24 students):

1. Content of the course: 1.5

2. Used self-assessment and self-evaluation methods and strategies: 1.7

3. Cooperation with the trainee: 1.3

4. Understanding of self-evaluation and self-assessment: 1.2

5. Influence of final evaluation of the course: 1.5

6. Importance of self-evaluation and self-assessment for quality of the learning: 1.6

7. Importance of self-evaluation and self-assessment for quality of students' work: 1.8

8. Cooperation with other students: 2.8

9. Greater responsibility for the learning: 1.9

10. Discrepancies between learner assessment and trainee assessment were resolved by negotiation: 1.4

The course was found to be useful by the trainee teacher and students. They felt confident in using both sets of materials. The majority of students also enjoyed the activity and learned new content. It would be good to think about whether group composition in particular class should be used or not. In conclusion the self-evaluation and self-assessment were used in a stimulating and motivating way.

Using the self-assessment approach we found that:

- Student self-evaluation is an integral part of student assessment;

- Alternative non-traditional student assessment provides a new perspective on learning;

- Trainers need to continue to develop implementation student assessment to enhance student learning;

- Trainers need to devote more time and effort to evaluation for formative purposes;

- The trainer's role is vital in developing a structured learning environment where students are given independence in their learning;

- The learning outcomes for students and trainers include the improvement of organization, evaluation skills, memory, personal growth, cooperation, reflective practice, self-reliance, independence and action planning;

- Self-assessment can help to solve the assessment in higher education institution;

- Reflection is critical part of this technique;

- Student learning is enhanced with self-assessment approach;

- Self-assessment and self-evaluation are improving quality of science teacher training.

- Students who are taught self-evaluation skills are more likely to persist on difficult tasks, be more confident about their ability, and take greater responsibility for their work. 
- When students are taught systematic self-evaluation procedures, the accuracy of their judgment improves.

- When students participate in the identification of the criteria that will be used to judge class production and use these criteria to judge their work, they get a better understanding of what is expected.

\section{Conclusion}

We base our expectations that a self-evaluation and self-assessment systems enhance student achievement on four arguments. Students will learn more because (i) self-evaluation will focus student attention on the objectives measured, (ii) the assessment provides teachers with information they would otherwise lack, (iii) students will pay more attention to the assessment, and (iv) student motivation will be enhanced.

As well, self-evaluation and self-assessment are unique in asking students to reflect on their performance. Self-assessment and self-evaluation procedures provide information about students' inner states during task performance, their subsequent interpretations about the quality of their work, and the goals they set in response to feedback. Self-evaluations that elicit information about students' effort, persistence, goals orientations, attributions for success and failure, and beliefs about their competence, give teachers a fuller understanding of why students perform as they do. When incorporated into teachers' deliberative planning they can anticipate impediments to learning, especially motivational obstacles.

Students view self-evaluation more positively than other kinds of assessment. Students like self-evaluation because it increased clarity about expectations, was fairer, and gave students feedback that they could use to improve the quality of their work (Ross et al., 1998).

Finally, self-evaluation has an indirect effect on achievement through self-efficacy (i.e., beliefs about one's ability to perform actions that lead to desired ends). What is crucial is how a student evaluates a performance. Positive self-evaluations encourage students to set higher goals and commit more personal resources to learning tasks (Bandura, 1997; Schunk, 1995). Negative self-evaluations lead students to embrace goal orientations that conflict with learning, select personal goals that are unrealistic, adopt learning strategies which are ineffective, exert low effort and make excuses for performance (Stipek, et al., 1992). Higher self-efficacy translates into higher achievement (Pajares, 1996).

One of the greatest challenges for teachers is the recalibration of power that occurs when assessment decisions are shared. Difficulty may be due to the fact that teaching students to be self-evaluators involves the implementation of fundamental changes in the relationship between teachers and students in the classroom. Changing root beliefs, behaviors and relationships is difficult and takes time (Posner et al., 1982). Accordingly, another challenge is time. Teachers need considerable time to work out how to accommodate an innovation that involves sharing control of a core teacher function with their existing beliefs about teacher and learner roles. As well, students need time to understand what self-evaluation is and how it relates to their learning, in addition to learning how to do it. Challenges such as these will demand that teachers be patient with the change process, for themselves and for their students.

\section{References}

Angelo T. A., Cross K. P. Classroom Assessment Techniques. San Francisco: Jossey-Bass Publisher, 1993. Second Edition. ISBN 1-55542-500-3.

Arter J., Spandel V., Culham R. \& Pollard, J. (1994). The impact of training students to be selfassessors of writing, paper presented at the Annual Meeting of the American Educational Research Association, New Orleans, April.

Bandura A. (1997). Self-efficacy: The exercise of control. New York: W. H. Freeman. 
Baron J. (1990). Performance assessment: Blurring the edges among assessment, curriculum and instruction, in: A. Champagne, B. Lovitts \& B. alinger (Eds.). Assessment in the Service of Instruction, 127-148. (Washington, DC, American Association for the Advancement of Science).

Bateson D. (1994). Psychometric and philosophical problems in "authentic" assessment: Performance tasks and portfolios, Alberta Journal of Educational Research, 40, 233-245.

Bellanca J., Bermam S. (1994). How to grade the thoughtful, cooperative classroom (if you must), paper presented at the International Conference on Cooperative Learning, Portland.

Briscoe C. (1994). Making the grade: Perspectives on a teacher's assessment practices, MidWestern Educational Researcher, 7, 14-16, 21-25.

Boud D. (1986). Implementing student self-assessment. Higher Education Research and Development, 5, 3-10.

Boud D. (1992). The use of self-assessment in student grading. Assessment and Evaluation in higher Education, 17, 185-200.

Bransford J. D., Brown A. L., Cocking R. R. (Ed) How People Learn. Brain, Mind, Experience, and School. Washington, D. C.: National Academy Press, 2000. First Edition. ISBN 0-309-07036-8.

Calfee R. (1993). Student portfolios: opportunities for a revolution in assessment, Journal of Reading, 36, 532-537.

Davies M.A., Wavering M. (1999). Alternative assessment: new directions in teaching and learning. Contenporary Education, 71(1), 39-45.

Dekkers P., Thijs G. (1998). Making Productive Use of Students' Initial Conceptions in Developing the Concept of Force. Science Education, 82, 31-51.

Dochy F. J. R. C., McDowell L. (1997). Introduction: assessment as a tool for learning. Studies in Educational Evaluation, 23, 279-298.

Dochy F., Segers M., Sluijsmans D. (1999). The use of self-, peer and co-assessment in higher education: a review. Studies in Higher Education, 24, 331-350.

Fredericksen J., Collins A. (1989). A systems approach to educational testing, Educational Researcher, 18, 27-32.

Garcia G., Pearson P. (1994). Assessment and diversity, in: L. Darling-Hammond (Ed.). Review of Research in Education, Vol. 20, 337-339 (Washington, DC, American Educational Research Association).

Hargreaves A., Fullan M. (1998). What's worth fighting for out there? Mississauga, ON: Ontario Public School Teachers' Federation.

Howell K., Bigelow S., Evoy, A. (1993). A qualitative examination of an authentic assessment, paper presented at the Annual Meeting of American Educational Research Association, Atlanta, GA.

Hughes B., Sullivan H., Mosley, M. (1985). External evaluation, task difficulty, and continuing motivation, Journal of Educational Research, 78, 210-215.

Laurillard D. (1997). Styles and approaches to problem solving. In: F. Marton, D. Hoinsell, N.J. Entwhistle (Eds.), The experience of learning ( $2^{\text {nd }}$ edition) (pp. 39-58). Edinburgh: Scottish Academic Press.

Linn R. (1994). Performance assessment: Policy, promises and technical measurement standards, Educational Researcher, 23, 4-14.

Linn R., Baker E., Dunbar S. (1991). Complex performance-based assessment: Expectations and validation criteria, Educational Researcher, 20(8), 15-21.

185.

Maehr M., Stallings R. (1972). Freedom from external evaluation, Child Development, 43, 177-

Maudaus G., Kellaghan T. (1993). The British experience with "authentic" testing, Phi Delta Kappan, 74, 458-469.

McMahon T. (1999). Using negotiation in summative assessment to encourage critical thinking. Teaching in Higher Education, 4(4), 549-554.

Novak J. (2002). Meaningful Learning: The Essential Factor for Conceptual Change in Limited or Inappropriate Propositional Hierarchies Leading to Empowerment of Learners. Science Education, 86(4), 548-571.

Pajares F. (1996). Self-efficacy beliefs in academic settings. Review of Educational Research, 66(4), 543-578.

Posner G., Strike K., Hewson P., Gertzog W. (1982). Accommodation of a Scientific Conception: Toward a Theory of Conceptual Change. Science Education, 66(2), 221-227. 
Raizen S., Kaser J. (1989). Assessing science learning in elementary school: What, why, and how?, Phi Delta Kappan, 70, 718-722.

Ross J. A., Rolheiser C., Hogaboam-Gray. (1999). Effects of collaborative action research on the knowledge of five Canadian teacher-researchers. The Elementary School Journal, 99(3), 255-274.

Ross J. A., Rolheiser C., Hogaboam-Gray. (1998). Skills training versus action research inservice: Impact on student attitudes on self-evaluation. Teaching and Teacher Education, 14(5), 463-477.

Sadler P.M., Good E. (2006). The impact of self- and peer-grading on student learning. Educational Assessment, 11, 1-31.

Shavelson R., Baxter G. \& Pine J. (1992). Performance assessments: Political rhetoric and measurement reality, Educational Researcher, 21, 22-27.

Schunk D. H. (1995). Goal and self-evaluative influences during children's mathematical skill acquisition. Paper presented at the annual meeting of the American Educational Research Association, San Francisco.

Stipek D., Roberts T., \& Sanborn M. (1984). Preschool-age children's performance expectations for themselves and another child as a function of the incentive value of success and the salience of past performance. Child Development, 59, 1983-1989.

Taras M. (2001). The use of tutor feedback and student self-assessment in summative assessment tasks: towards transparency for students and tutors. Assessment and Evaluation in Higher Education, 26, 605-614.

Valanides N., Hadjiachilleos N. (2006). Cognitive Conflict and its Effects on Conceptual Change in Science: Two Scenarios from the Domain of Physics. Paper presented at the Joint North American, European, and South American Symposium on Science and Technology Literacy for the 21st Century. May 31st- June 4th, 2006, Nicosia, Cyprus

Wiggins G. (1993). Assessing Student Performance: Explore the purpose and limits of testing (San Francisco, CA, Jossey-Bass).

Wilson R. (1992). The context of classroom processes in evaluating students, in: D. Bateson (Ed.). Classroom Testing in Canada, 3-10. Vancouver, BC: University of British Columbia.

Worthen B. (1993). Critical issues that will determine the future of alternate assessment, Phi Delta Kappan, 74, 444-457.

Received 20 January 2009; accepted 20 August 2009

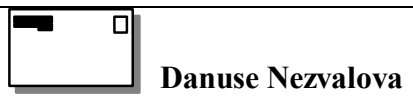

Professor, Palacký University, Faculty of Science, tř. 17. listopadu 1192/12

77146 Olomouc, Czech Republic.

E-mail: danuse.nezvalova@upol.cz

Website: http://www.upol.cz 